\title{
Progesterone improves the maturation of male-induced preovulatory follicles in anoestrous ewes
}

\author{
Achraf Adib 1,2,3,4, Sandrine Freret ${ }^{1,2,3,4}$, Jean-Luc Touze $\mathrm{A}^{1,2,3,4}$, Didier Lomet ${ }^{1,2,3,4}$, \\ Lionel Lardic 1,2,3,4, Didier Chesneau 1,2,3,4, Anthony Estienne ${ }^{1,2,3,4}$, Pascal Papillier ${ }^{1,2,3,4}$, \\ Danielle Monniaux ${ }^{1,2,3,4}$ and Maria-Teresa Pellicer-Rubio ${ }^{1,2,3,4}$
}

${ }^{1}$ Institut National de la Recherche Agronomique, UMR85 Physiologie de la Reproduction et des Comportements, F-37380 Nouzilly, France, ${ }^{2}$ Centre National de la Recherche Scientifique, UMR 7247, F-37380 Nouzilly, France, ${ }^{3}$ Université François Rabelais de Tours, F-37041 Tours, France and ${ }^{4}$ Institut Français du Cheval et de l'Equitation, F-37380 Nouzilly, France

Correspondence should be addressed to M-T Pellicer-Rubio; Email: Maria-Teresa.Pellicer@tours.inra.fr

\begin{abstract}
The first ovulation induced by male effect in sheep during seasonal anoestrus usually results in the development of a short cycle that can be avoided by progesterone priming before ram introduction. In elucidating the involvement of the hypothalamic-pituitary-gonadal axis in the occurrence of short cycles, the effects of progesterone and the time of anoestrus on the development of male-induced preovulatory follicles were investigated in anoestrous ewes using morphological, endocrine and molecular approaches. Ewes were primed with progesterone for 2 (CIDR2) or 12 days (CIDR12) and untreated ewes used as controls during early (April) and late (June) anoestrus. The duration of follicular growth and the lifespan of the male-induced preovulatory follicles were prolonged by $\sim 1.6$ days in CIDR12 ewes compared with the controls. These changes were accompanied by a delay in the preovulatory LH and FSH surges and ovulation. Intrafollicular oestradiol concentration and mRNA levels of LHCGR and STAR in the granulosa and theca cells of the preovulatory follicles were higher in CIDR12 ewes than the control ewes. The expression of mRNA levels of CYP11A1 and CYP17A1 also increased in theca cells of CIDR12 ewes. CIDR2 ewes gave intermediate results. Moreover, ewes ovulated earlier in June than in April, without changes in the duration of follicular growth, but these effects were unrelated to the lifespan of corpus luteum. Our results give the first evidence supporting the positive effect of progesterone priming on the completion of growth and maturation of preovulatory follicles induced by male effect in seasonal anoestrous ewes, thereby preventing short cycles.
\end{abstract}

Reproduction (2014) 148 403-416

\section{Introduction}

The male effect is a natural and efficient way to induce ovulation and synchronise mating and lambing in a flock of sheep outside the breeding season. Indeed, it is known that the introduction of sexually active males into a flock of anovulatory ewes stimulates luteinizing hormone (LH) secretion from the anterior pituitary, resulting in a rapid increase in $\mathrm{LH}$ pulse frequency and the triggering of a preovulatory LH surge (Walkden-Brown et al. 1999) and ovulation within three days.

The first ovulation induced by the male is highly synchronised and could be very interesting in the application of artificial insemination. However, ewes do not go into oestrus at this first ovulation (silent ovulation), and the resulting corpus luteum is short-lived after a transitory progesterone release in some ewes, leading to the development of a short cycle. These can be avoided by priming the ewes with progesterone before introduction of the ram. Progesterone treatment given for a long term
(12-16 days) before ram introduction results in the development of a normal cycle at the first male-induced ovulation with the ewes exhibiting oestrus (Cognié et al. 1982). However, short-term progesterone pre-treatment ( 2 days) leads to normal cycles, but without oestrus (McLeod \& Haresign 1984).

It appears that the different levels of the reproductive axis (hypothalamus, pituitary, ovary and uterus) are implicated in the mechanism underlying the development of male-induced short cycles (Legan et al. 1985a, Chemineau et al. 2006). Involvement of the uterus in early luteolysis has been widely documented (Cognié et al. 1982, Oldham et al. 1985, Pearce et al. 1985, 1987, Vallet et al. 1990, Lassoued et al. 1997). At the ovarian level, recent findings have suggested that a failure of luteal expression of genes encoding the prostaglandin F2 $\alpha$ receptor, some key proteins involved in the biosynthesis of progesterone as well as some vascular development factors is associated with maleinduced short cycles in the ewe, such effects being 
counteracted by progesterone priming (Brown et al. 2014). The current working hypothesis proposes poor follicular quality as the key event resulting in the subsequent failure of luteinisation (Legan et al. 1985a, Hunter et al. 1986, Chemineau et al. 2006, Pellicer-Rubio et al. 2012). In addition, it is now well known that male-induced short cycles are not associated with premature LH surges (Pearce et al. 1987). However, insufficient secretion of $\mathrm{LH}$ and FSH remains an obvious hypothesis to explain poor follicular quality during seasonal anoestrus (Bartlewski et al. 2001).

In this study, we analysed the hypothesis supporting the involvement of inadequate follicular development and/or poor hypothalamic-pituitary activity in the occurrence of male-induced short cycles in sheep, such effects being able to be countered by progesterone priming. For this purpose, we investigated the influence of progesterone and the time of the seasonal anoestrus on the growth dynamics of male-induced preovulatory follicles together with key endocrine signals involved in final follicular growth and ovulation. Moreover, we investigated the effect of progesterone priming on the maturation of those male-induced preovulatory follicles by measuring some representative markers of follicular function, including the intra-follicular concentrations of oestradiol-17 $\beta\left(E_{2}\right)$ and progesterone, and the expression of genes encoding the steroid acute regulatory protein (STAR), steroidogenic enzymes (CYP11A1, CYP17A1 and CYP19A1), gonadotrophin receptors (FSHR and LHCGR), an angiogenic factor (VEGFA (VEGF)) and the alpha-inhibin subunit (INHA), in granulosa and theca cells.

\section{Materials and methods}

\section{Animals}

Two experiments were carried out on anovulatory Ile-de-France ewes during seasonal anoestrus. In both experiments, ewes were selected from a group of healthy primiparous and multiparous Ile-de-France ewes of the flock at the INRA Experimental Unit of Animal Physiology (Nouzilly, France; latitude $46^{\circ} \mathrm{N}$ ). Ewes from the first experiment were $2-4$ years old, with an average body weight of $63.9 \pm 8.6 \mathrm{~kg}$ and a body condition score of $3.1 \pm 0.3$ on a scale of 0 (emaciated) -5 (obese). In the second experiment, ewes were of the same age with an average weight of $58 \pm 6.6 \mathrm{~kg}$ and a body condition score of $2.8 \pm 0.2$. All ewes had normal reproductive histories and had lambed during the previous year.

The anovulatory status of ewes was determined by measuring the progesterone concentration in blood samples collected once a week for 3 consecutive weeks before starting the trials. Ewes were considered anovulatory when plasma progesterone was $<0.75 \mathrm{ng} / \mathrm{ml}$ in the three samples (Thimonier et al. 2000). In addition, transrectal ultrasonography of ovaries was conducted during the week preceding the allotment of the ewes (see section 'Experiment 1: effect of the length of progesterone treatment on the growth dynamics of the preovulatory follicles induced by male effect') in order to confirm the absence of corpora lutea.

Adult rams were part of the same flock. Rams and ewes were kept in separate barns before the beginning of experiments where they were given daily maintenance diets and water ad libitum.

All procedures were conducted in accordance with the guidelines for the Care and Use of Agricultural Animals in Agricultural Research and Teaching. Care and handling of experimental animals and the procedures were carried out according to the recommendations of the Val de Loire regional ethic committee (CEEAVdL).

\section{Experiment 1: effect of the length of progesterone treatment on the growth dynamics of the preovulatory follicles induced by male effect}

\section{Experimental design}

The experimental protocol is illustrated in Fig. 1A. The male effect was carried out in 32 anovulatory ewes twice during the anoestrous season when most ewes are not cycling (Chanvallon et al. 2011), i.e. April $(n=16)$ and June $(n=16)$. During each anoestrous season, their body weight, body condition score and the mean number of ovarian follicles with a diameter $\geq 2 \mathrm{~mm}$ (measured twice 2 days apart by transrectal ultrasonography, see below) were determined during the week following diagnosis of their anovulatory status. These parameters were taken into account for the allotment of ewes into three homogenous groups. The control group $(n=8)$ received no hormonal treatment, the CIDR2 group $(n=4)$ were given a short-term progesterone treatment using intra-vaginal progesterone-release devices (Controlled Internal Drug Release EAZI-BREED CIDR, 0.3 g progesterone, Pfizer) for 2 days and the CIDR12 group $(n=4)$ had long-term progesterone treatment (CIDR for 12 days) before ram introduction. The number of ewes in the control group was doubled because two types of cycles were expected (short and normal cycles) following the first ovulation induced by the male (Pellicer-Rubio et al. 2012), instead of only one (normal cycles) in ewes primed with progesterone (Pearce et al. 1987). The CIDR was removed $24 \mathrm{~h}$ before the day of ram introduction (D0).

Rams used for male effect had been subjected to long-day treatment ( $16 \mathrm{~h}$ light: $8 \mathrm{~h}$ darkness) for 60 days followed by short-day treatment ( $8 \mathrm{~h}$ light: $16 \mathrm{~h}$ darkness) for 50 days, to stimulate their sexual activity and standardise the level of stimulation, regardless of the time of anoestrus (Chemineau et al. 1992, Rosa \& Bryant 2002). During each seasonal anoestrus, the 16 females were exposed under a natural photoperiod to three sexually active rams (D0) at the end of the male's short-day treatment (April 4 in the first trial and June 6 in the second trial). Rams were left with the ewes for 25 days. Sexual activity of males was measured throughout the photoperiodic treatment and during the male effect by the changes in testicular weight using an orchidometer. Changes in testicular weight throughout the photoperiodic treatment were similar in both groups of rams and no difference was observed between D0 and D25 (data not shown). 

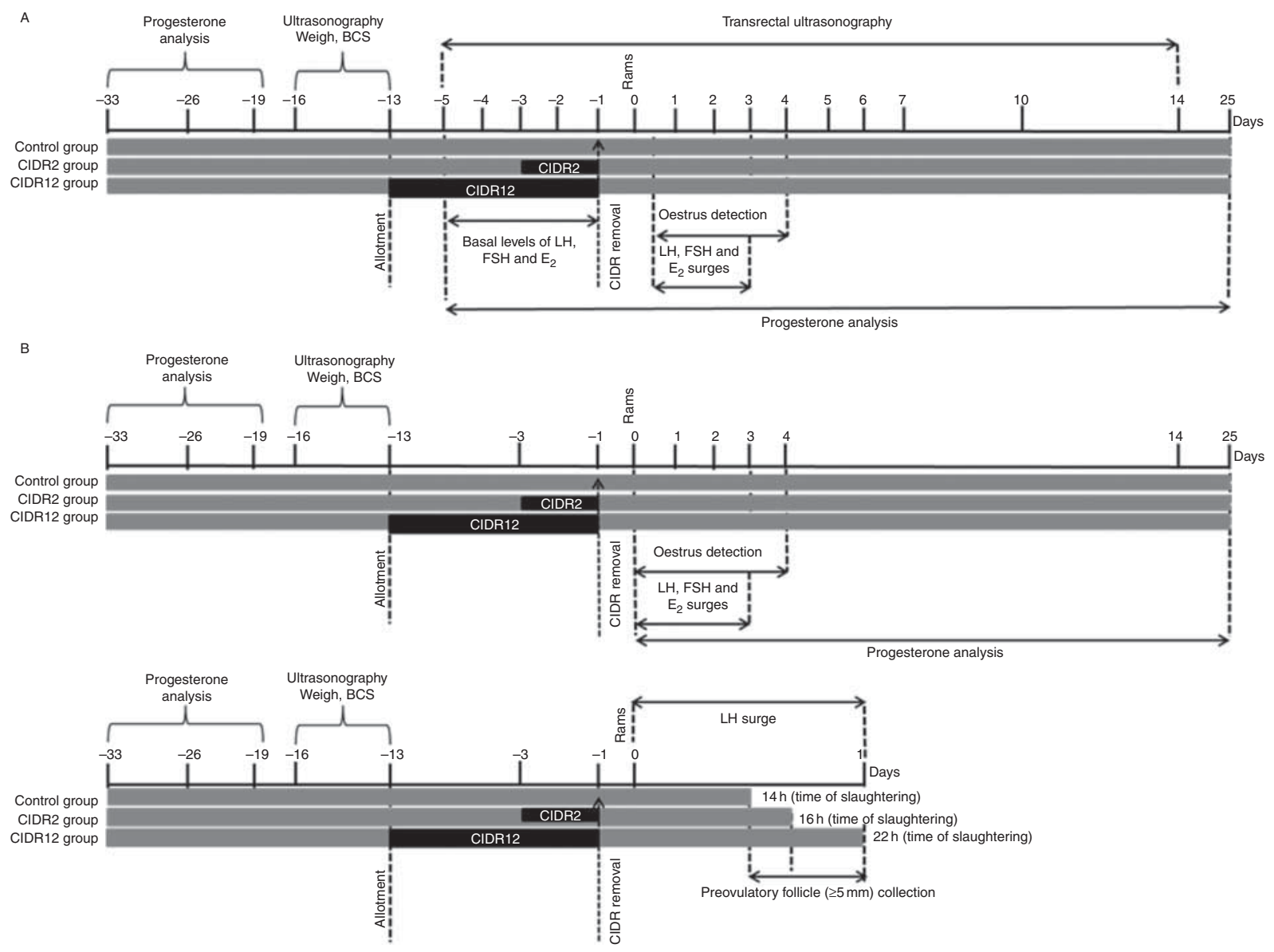

Figure 1 Schematic representation of the experimental protocols. (A) Experiment 1 was aimed to investigate the influence of progesterone priming and the time of the seasonal anoestrus on the growth dynamics of the preovulatory follicles induced by male effect. The male effect was carried out on anovulatory ewes in April $(n=16)$ and June $(n=16)$. (B) Experiment 2 was aimed to investigate the effect of progesterone priming on the maturation of the preovulatory follicles induced by male effect. The male effect was carried out on anovulatory ewes in June. In the experimental group (lower panel, $n=30$ ), ewes were slaughtered within $12 \mathrm{~h}$ before the expected $\mathrm{LH}$ surge to collect ovarian follicles $\geq 5 \mathrm{~mm}$ and examine the expression of follicular maturation markers. In the monitoring group (upper panel, $n=30$ ), ewes were not slaughtered to determine the mean time of the LH surge and the type of the first cycle (normal or short) induced by the male. In both experiments, ewes from the control group received no hormonal treatment, the CIDR2 group were given a progesterone treatment for two days, and the CIDR12 group had progesterone treatment for 12 days before ram introduction (see 'Materials and methods' section for details).

\section{Oestrus detection}

Oestrous behaviour was recorded twice daily from D0 to D4 by direct observation of ewes marked by rams equipped with marking harnesses. Immobilisation of the ewes was noted as a sign of both proceptivity and receptivity (Fabre-Nys \& Gelez 2007).

\section{Ultrasound scanning of ovaries and determination of ovarian parameters}

Ovaries were monitored daily (starting at $0900 \mathrm{~h}$ ) from D-5 to D7, then at D10 and D14, by transrectal ultrasonography using a $7.5 \mathrm{MHz}$ linear transducer (ALOKA-SSD 900, Japan Care Co. Ltd, Kobe-Shi, Japan) with the ewes in standing position (Duggavathi et al. 2003). All follicles $\geq 2 \mathrm{~mm}$ and luteal structures were counted and measured, and both ovaries were mapped daily. Ovarian examinations were videorecorded for retrospective analyses of the sketches obtained.

The population of ovarian follicles was followed during the period preceding ram introduction (from D-5 to D0). Follicles were categorised by their diameter as small $(2-3.5 \mathrm{~mm})$, medium (3.6-4.5 mm) and large $(\geq 4.6 \mathrm{~mm})$. The daily mean number of follicles in each size class, the daily mean number of total follicles and the maximal follicular size were calculated for this period and for each ewe.

The growth pattern of the preovulatory follicles was followed for each ewe from D-5 to D7. The diameter and position of follicles $\geq 3 \mathrm{~mm}$ were recorded daily. The growth and regression patterns of each follicle were established by comparing its diameter with that of the previous day, and on subsequent days until ovulation. A preovulatory follicle was considered in a growing, stationary or regressing phase when 
its diameter increased by $\geq 0.5 \mathrm{~mm}$, remained unchanged ( $\pm 0.4 \mathrm{~mm}$ ), or decreased by $\geq 0.5 \mathrm{~mm}$ compared with that of the previous day respectively. The day of emergence was the day on which the preovulatory follicle was 3-4 mm in diameter (Medan et al. 2003). The size of the preovulatory follicle at D0 and the day of maximum size were recorded. The duration of follicular growth (days) was defined as the time between the day of emergence and the day of maximum size. The follicular growth rate was calculated as the ratio, 'maximum diameterdiameter at emergence/duration of follicular growth'. The day of ovulation was defined as the day of disappearance of a large follicle on ultrasonographic images (Ravindra et al. 1994). The ovulatory size was defined as the diameter of the preovulatory follicle on the day preceding ovulation. The follicle lifespan was defined as the time (days) between the day of emergence and the day of ovulation.

Ovaries were also scanned at D7, D10 and D14 to confirm the ovulation rate by counting the number of luteal structures. When one ewe had two or more ovulations, mean values of follicular parameters were used for subsequent comparative analysis between groups of ewes.

\section{Blood sampling and hormonal parameters}

Before ram introduction, blood samples were collected by venipuncture twice a day from D-5 to D0 to characterise the basal endocrine levels of $\mathrm{FSH}, \mathrm{LH}$ and $\mathrm{E}_{2}$. After ram introduction, blood samples were collected every $4 \mathrm{~h}$ (conventional blood sampling frequency to determine the time of the $\mathrm{LH}$ surge) for $72 \mathrm{~h}$ to measure the preovulatory surges of $\mathrm{LH}$, $\mathrm{FSH}$ and $\mathrm{E}_{2}$. All blood samples were collected in heparinised tubes and centrifuged immediately at $4000 \mathrm{~g}$ for $30 \mathrm{~min}$ at $4{ }^{\circ} \mathrm{C}$ to recover the plasma, which was stored at $-20^{\circ} \mathrm{C}$ until hormone assays were carried out.

The $\mathrm{LH}$ surge was defined as an increase in the $\mathrm{LH}$ plasma concentration higher than the baseline plus twice the s.D. in at least two consecutive samples and exceeding $10 \mathrm{ng} / \mathrm{ml}$ at least in one sample (Sebert et al. 2010). The LH baseline was the mean LH plasma concentration ( \pm the S.D.) calculated from samples collected from ram introduction (D0) to the first sample in which the LH plasma concentration was $\geq 10 \mathrm{ng} / \mathrm{ml}$ (excluding this one), for a given ewe.

The FSH surge was defined as an increase in the FSH plasma concentration concomitant with the $\mathrm{LH}$ surge and superior to the FSH baseline plus twice the s.D. The FSH baseline was defined as the mean FSH plasma concentration ( \pm the S.D.) calculated from the same samples considered for the $\mathrm{LH}$ baseline analysis, for a given ewe.

The $\mathrm{LH}$ and $\mathrm{FSH}$ preovulatory surges were characterised by the time of the surge (maximal concentration), the duration of the surge and the total amount of hormone released during the surge, expressed as area under the curve (AUC-LH and AUC$\mathrm{FSH}$ ). The AUC was calculated between the baseline and the curve using the trapezoidal rule (GraphPad Prism version 5.0 for windows, GraphPad Software, San Diego, California, USA). We considered only the points above the baseline to be part of peaks. The first and the last points delimiting the surges were calculated automatically by the program taking into account the baseline information provided; these points were also used to compute the duration of the surge. AUC results were expressed as surface arbitrary units (SAUs).

The total amount of $E_{2}$ released from male introduction to the $\mathrm{LH}$ surge $\left(\mathrm{A} \cup \mathrm{C}-\mathrm{E}_{2}\right)$, and the amount of $\mathrm{E}_{2}$ released within $12 \mathrm{~h}$ preceding the $\mathrm{LH}$ surge $\left(\mathrm{AUC}-\mathrm{E}_{2}\right.$ within $12 \mathrm{~h}$, defined as a critical period of $\mathrm{E}_{2}$ secretion to induce the $\mathrm{LH}$ surge (Ben Said et al. 2007), was also measured. In this case, the total AUC was considered without subtracting the baseline.

The ovulatory response of ewes to the male effect was characterised by analysing the plasma progesterone profiles from blood samples collected once a day from D0 to D25. Luteal activity was defined as an increase in the progesterone plasma concentration superior to the baseline plus twice the s.D. The progesterone baseline was defined as the mean plasma concentration calculated from samples collected from D0 (ram introduction) to D3, for a given ewe. A normal cycle was defined as the presence of luteal activity with progesterone levels $>1 \mathrm{ng} / \mathrm{ml}$ for at least 10 days, indicating a luteal phase duration of $>12$ days (Chanvallon et al. 2011). A short cycle was defined as the presence of luteal activity for 1-2 days, indicating that ovulation had occurred, but the luteal phase was shortened to $<3$ days (Chemineau et al. 2006, Chanvallon et al. 2011).

\section{Experiment 2: effect of the length of progesterone treatment on the maturation of the preovulatory follicles induced by male effect}

\section{Experimental design}

The experimental protocol is illustrated in Fig. 1B. Experiment 2 involved a total of 60 anovulatory Ile-de-France ewes divided into three homogenous groups, as in Experiment 1: control group $(n=20)$, CIDR2 group $(n=20)$ and CIDR12 group $(n=20)$. The CIDR devices were removed $24 \mathrm{~h}$ before the day of ram introduction (D0). The anovulatory ewes were exposed to the male effect using a ratio of one male to six ewes. In this experiment, the males were not subjected to a photoperiodic treatment. Following the introduction of rams, one half of the ewes from each group were slaughtered within $12 \mathrm{~h}$ before the expected LH surge (critical follicular maturation period before ovulation; Ben Said et al. 2007), to collect ovarian follicles $\geq 5 \mathrm{~mm}$ and examine the expression of follicular maturation markers. The times at which ewes were slaughtered were chosen from the results of Experiment 1, which had established the time of the LH surge (see section 'Experiment 1: effect of the length of progesterone treatment on the growth dynamics of the preovulatory follicles induced by male effect'). Ewes were slaughtered 14, 16 or $22 \mathrm{~h}$ following the introduction of males in control, CIDR2 and CIDR12 groups respectively. Blood samples were also collected every $4 \mathrm{~h}$ following ram introduction up to slaughtering of the ewes to measure LH plasma concentrations and verify that ewes had not had the LH surge.

The other half of ewes of the experimental groups were not slaughtered, but were retained with males for 25 days to determine the mean time of the $\mathrm{LH}$ surge and the type of the first cycle (normal or short) induced by the male. Oestrous behaviour was recorded twice daily from days 0 to 4 as described above. Blood samples were collected from D0 
every $4 \mathrm{~h}$ for $72 \mathrm{~h}$ to follow the occurrence of the $\mathrm{LH}$ surge. The type of the cycle induced by the male effect (short or normal cycle) was determined by analysis of plasma progesterone profiles in blood samples collected daily from D0 to D25.

The male effect was carried out in subgroups of 12 ewes (four ewes per treatment) in a sequential manner 2-3 days apart over 3 consecutive weeks (from 29th May to 13th June). Under these experimental conditions, at each slaughtering time, two ewes were slaughtered in an interval of $15 \mathrm{~min}$.

\section{Follicular fluid and cell collection}

Immediately after ewes had been slaughtered, ovaries were finely dissected to isolate individual antral follicles $\geq 5 \mathrm{~mm}$ in diameter. To analyse intra-follicular concentrations of $E_{2}$ and progesterone, follicular fluids were recovered individually with a syringe needle and stored at $-20{ }^{\circ} \mathrm{C}$ until assayed. For mRNA expression of follicular maturation markers, granulosa and theca cells were also recovered from the follicles separately, as described previously (Monniaux \& Pisselet 1992) and stored at $-80{ }^{\circ} \mathrm{C}$ before RNA extraction. Atresia of granulosa cells was assessed by microscopic examination of Feulgen-stained granulosa cell smear. Follicles were classified as atretic or non-atretic according to the presence or absence of pycnotic nuclei on the smears (Monniaux 1987).

\section{$R T$ and quantitative PCR}

Total RNA was extracted from granulosa and theca cell samples using the Nucleospin RNA II Kit (Macherey-Nagel, Hoerdt, France), which was diluted at $0.5 \mu \mathrm{g} / \mu \mathrm{l}$ in RNase-free water. Total RNA was reverse transcribed and analysed by real-time PCR for quantification of the expression of the following ovarian follicular genes encoding the steroid acute regulatory protein (STAR), steroidogenic enzymes (CYP11A1, CYP17A1 and CYP19A1), gonadotrophin receptors (FSHR and LHCGR), an angiogenic factor (VEGFA) and alpha-inhibin subunit (INHA).

RNA $(1 \mu \mathrm{g})$ was reverse transcribed using MMLV reverse transcriptase $(200 \mathrm{U})$ in the presence of oligo (dT) (500 ng), dNTP (0.04 mM) and RNAsine (RNAse inhibitor, $20 \mathrm{U}$ ) (all products from Promega) at $42{ }^{\circ} \mathrm{C}$ for $1 \mathrm{~h}$.

Each PCR consisted of $20 \mu \mathrm{l}$ containing $5 \mu \mathrm{l}$ diluted cDNA (between $1 / 10$ and 1/100), $0.15 \mu \mathrm{mol}$ of each primer and $10 \mu \mathrm{l}$ $2 \times$ IQ SYBR Green Supermix (Bio-Rad) in 96-well plates. PCRs running without cDNA (water blank), on the one hand, and with total RNA (non-reverse-transcribed) to check for the absence of genomic DNA contamination, on the other hand, served as negative controls. The real-time quantitative PCR was run on iCycler iQ Multicolor Detection System (Bio-Rad Laboratories, Inc., Hercules, Californie, USA); Monniaux et al. 2008). The cycling conditions were one cycle of denaturation at $95^{\circ} \mathrm{C} / 3 \mathrm{~min}$, followed by 40 three-segment cycles of amplification $\left(95^{\circ} \mathrm{C} / 30 \mathrm{~s}, 58^{\circ} \mathrm{C} / 30 \mathrm{~s}\right.$ and $\left.72{ }^{\circ} \mathrm{C} / 30 \mathrm{~s}\right)$. The baseline adjustment method of the iCycler Software (Bio-Rad Laboratories, Inc., Hercules, Californie, USA) was used to determine the cycle threshold $(C t)$ in each reaction. A melting curve was constructed for each primer pair to verify the presence of one gene-specific peak and the absence of primer dimer, further controlled by agarose gel migration of the amplicon. For each primer pair, efficiency curves were generated using serial dilutions of cDNA of granulosa cells in the abscissa and the corresponding $C t$ in the ordinate. The slope of the log-linear phase reflects the amplification efficiency $(E)$ derived from the formula $E=\mathrm{e}^{(-1 / \mathrm{slope})}$. For quantification, the $C t$ of target gene (for example, CYP19A1) was compared with the internal reference gene RPL19 encoding a ubiquitous ribosomal protein, according to the ratio: $R=\left(E_{\mathrm{RPL} 19}\right)^{C \mathrm{t}(\mathrm{RPL} 19)} /\left(E_{\text {target }}\right)^{C \mathrm{t}(\text { target })}$.

The specific primer sequences used for each gene and the amplification efficiency for each primer are detailed in Table 1. As there are several transcripts encoding the $\mathrm{LH}$ receptor in the ovary of sheep (the full-length LHCGR1 mRNA and two splice variants; Bacich et al. 1994, Abdennebi et al. 2002), LHCGR primers were designed between exons 9 and 11 to confirm the presence of the three variants by the amplification of a region of 397 bp for LHCGR1 mRNA, 304 bp for LHCGR2 mRNA and $131 \mathrm{bp}$ for LHCGR3 mRNA. PCR products from granulosa and theca cells were analysed on $1.5 \%$ ethidium bromide agarose gels (results are not shown) and the amplification of all three variants was confirmed in both cellular types. LHCGR3 seems to be the major form of the mRNA encoding $\mathrm{LH}$ receptor in both theca and granulosa cells as described previously (Abdennebi et al. 2002).

\section{Hormonal analysis}

Plasma concentrations of progesterone, LH and FSH were measured by enzymatic immunoassays as before (Faure et al. 2005, Canepa et al. 2008). The sensitivity of the progesterone

Table 1 Quantitative PCR primer sequences and efficiency of the PCRs.

\begin{tabular}{|c|c|c|c|c|c|}
\hline \multirow[b]{2}{*}{ Genes } & \multicolumn{2}{|c|}{ Primer sequences } & \multirow[b]{2}{*}{ Accession number } & \multirow{2}{*}{$\begin{array}{l}\text { Product } \\
\text { size }(b p)\end{array}$} & \multirow[b]{2}{*}{ Efficiency } \\
\hline & Forward $\left(5^{\prime} \rightarrow 3^{\prime}\right)$ & Reverse $\left(5^{\prime} \rightarrow 3^{\prime}\right)$ & & & \\
\hline LHCGR & AAACTTGCCAACAAAAGAG & CAATGAGTAGCAGGTAGAG & NM_001278566.1 & $397,304,131$ & 1.94 \\
\hline$F S H R$ & CAAAGATCСТССТGGTCСTGTTC & GTTCCTGGTGAAGATGGCGTAG & NM_001009289.1 & 77 & 1.88 \\
\hline CYP19A1 & TCATCCTGGTCACССТTСТG & CGGTCGCTGGTCTCGTCTGG & AJ012153.1 & 115 & 1.95 \\
\hline CYP11A1 & CGGACAAGTTTGACCCAACCAG & GGCGGAAGACAAGGAAGATGG & NM_001093789.1 & 243 & 1.95 \\
\hline CYP17A1 & CTTACCATTGACAAAGGCACAGAC & GCTTAATGATGGCGAGATGAGTTG & NM_001009483.1 & 144 & 1.95 \\
\hline STAR & ACACCATGTGGAATGTCAGGCT & CACACСТTTCAACAAGCAACCC & NM_001009243.1 & 263 & 2 \\
\hline INHA & GACCAAGATGTCTCCCAG & CAGTATGGAACCACAGCT & XM_004004955.1 & 166 & 2 \\
\hline VEGFA & GAGAGATGAGTTTCCTACAG & GCAAGTACGTTCGTTTAAC & EU857623.1 & 200 & 2.03 \\
\hline RPL 19 & AATGCCAATGCCAACTC & СССТTTCGСТАССТАTACC & XM_004012836.1 & 155 & 1.95 \\
\hline
\end{tabular}


assay was $0.4 \mathrm{ng} / \mathrm{ml}$, with intra- and inter-assay coefficient of variation $(\mathrm{CV})$ values being 4 and $9 \%$ respectively. The sensitivities of the $\mathrm{LH}$ and $\mathrm{FSH}$ assays were 0.1 and $0.2 \mathrm{ng} /$ $\mathrm{ml}$, respectively, with intra- and inter-assay $\mathrm{CV}$ values being 4 and $10 \%$ for $\mathrm{LH}$, and 2.6 and $2.1 \%$ for $\mathrm{FSH}$ respectively.

Plasma concentrations of $E_{2}$ were measured using a DIASource Immunoassay Kit ( $E_{2}-E I A$ CT/KAP0621, DIASource Immunoassay SA, Louvain la Neuve, Belgium), adapted to ovine plasma after extraction (Ben Said et al. 2007, Lardic et al. 2012). The sensitivity of the assay was $0.8 \mathrm{pg} / \mathrm{ml}$, and the intraand inter-assay CV values were 11.9 and $11.7 \%$ for $1 \mathrm{pg} / \mathrm{ml}$ reference samples and 4.6 and $4.7 \%$ for $5 \mathrm{pg} / \mathrm{ml}$ reference samples respectively.

In ovine follicular fluids, $E_{2}$ concentrations were measured using the same DIASource Immunoassay Kit in a direct assay. According to the follicular status based on the level of atresia of granulosa cells, each sample was diluted from $1 / 100$ to $1 / 25$ 000. Intra-assay CV values were 8.4 and $6.3 \%$ for 5 and $100 \mathrm{pg} / \mathrm{ml}$ samples respectively. From the results of six assays, inter-assay CV values were 10.6 and $5.8 \%$ for 5 and $100 \mathrm{pg} / \mathrm{ml}$ samples respectively. Cross-reactivities (tested by DIAsource) were $<2 \%$ for oestrone, oestriol, $E_{2}$-3-glucuronide and $\mathrm{E}_{2}$-17-glucuronide and $<0.1 \%$ for $\mathrm{E}_{2}-17$-valerate, cortisol, progesterone, DHEA-sulphate, testosterone, androstenediol, norgestrel, premarin and equilin.

\section{Statistical analysis}

Statistical analyses were performed using the SAS Software 9.3 (SAS Institute, Inc., 2011, Cary, North Carolina, USA) or the Graph Pad PRISM 5 Software (GraphPad Prism version 5.0 for windows, GraphPad Software, San Diego, California, USA), with tests adapted to the particular variables involved.

Comparison of frequencies used Fisher's exact test (SAS FREQ procedure). According to the normality of the quantitative variables, means were compared either by ANOVA (SAS GLM procedure) followed by multiple comparisons using the Bonferroni's adjustment or the Mann-Whitney-Wilcoxon test (SAS NPAR1WAY procedure). Pearson or Spearman correlations between quantitative variables were also calculated (Graph Pad PRISM 5).

Depending on the variables, arithmetic means \pm S.E.M. or median \pm interquartile ranges are given in the results, figures and tables. Differences were considered statistically significant when $P \leq 0.05$. Tendencies were noted when $0.05<P \leq 0.1$.

\section{Results}

\section{Experiment 1: effect of the length of progesterone treatment on the growth dynamics of the preovulatory follicles induced by male effect}

Oestrous behaviour, ovulation and quality of cycle

Oestrous behaviour was observed within 3 days following ram introduction in all ewes from the CIDR12 group (8/8) and only one of the eight ewes from the CIDR2 group. No ewe from the control group was in oestrus (Table 2 ). The time of the
Table 2 Number of ewes in oestrus, displaying the LH surge, ovulating and developing normal or short cycles after male exposure.

\begin{tabular}{lcccl}
\hline & Control & CIDR2 & CIDR12 & $\begin{array}{c}\text { Fisher's } \\
\text { exact test }\end{array}$ \\
\hline $\begin{array}{l}\text { Total number of ewes } \\
\text { Ewes in oestrus }\end{array}$ & 16 & 8 & 8 & \\
$\quad($ D0-D4) & 0 & 1 & 8 & $P<0.0001$ \\
$\begin{array}{l}\text { Ewes with LH surge } \\
\quad(0-72 \text { h) }\end{array}$ & 16 & 7 & 8 & $\mathrm{NS}$ \\
$\begin{array}{l}\text { Ewes ovulating } \\
\quad(\text { D0-D4) }\end{array}$ & 16 & 7 & 8 & $\mathrm{NS}$ \\
$\begin{array}{l}\text { Ewes with short } \\
\quad \begin{array}{l}\text { cycles } \\
\text { Ewes with normal }\end{array}\end{array}$ & 14 & 0 & 0 & $P<0.0001$ \\
$\quad$ cycles & 2 & 7 & 8 & $P<0.0001$ \\
\hline
\end{tabular}

$P$, Fisher's exact test (NS, not significant when $P>0.1$ ). Control, untreated ewes; CIDR2, ewes treated with progesterone for 2 days; CIDR12, ewes treated with progesterone for 12 days. Data from April and June were combined.

seasonal anoestrus did not influence the expression of oestrus $(P>0.1)$.

Most ewes $(31 / 32 ; 97 \%)$ had a preovulatory LH surge and ovulated with a mean number of $1.4 \pm 0.1$ ovulations (range 1-3 ovulations) occurring within 4 days following male introduction. Only one ewe from the CIDR2 group failed to ovulate in April (Table 2). Neither the time of the seasonal anoestrus nor the length of progesterone treatment had any effect on these parameters $(P>0.1)$.

Following ovulation induced by the male, the incidence of normal cycles approached $13 \%(2 / 16)$ in the control group, whereas the remaining control ewes developed a short cycle $(88 \% ; 14 / 16)$. By contrast, all progesterone-treated ewes (CIDR2 and CIDR12 groups) developed a normal cycle as anticipated (Table 2). The frequency of normal and short cycles in each group of ewes was similar $(P>0.1)$ in April and June.

\section{Follicular population and basal endocrine levels of $\mathrm{FSH}, \mathrm{LH}$ and $\mathrm{E}_{2}$ before male introduction}

Before ram introduction (from D-5 to D0), the length of progesterone treatment did not influence the number of small, medium and large follicles ( $P>0.1$; Table 3$)$. By contrast, the maximum follicular diameter was smaller in ewes from the CIDR12 group compared with the control one $(5.2 \pm 0.1$ vs $5.9 \pm 0.1 \mathrm{~mm} ; P \leq 0.05)$, whereas the maximum diameter of the CIDR2 group $(5.6 \pm 0.1 \mathrm{~mm})$ was similar $(P>0.1)$ to CIDR12 and control ewes. This was accompanied by a lower $(P=0.07)$ plasma $\mathrm{E}_{2}$ concentration in the CIDR12 group. $E_{2}$ and LH concentrations were positively correlated $(r=0.47, P \leq 0.05)$.

The time of anoestrus had an effect on the number of large follicles (Table 3), which was higher in June than in April $(1.7 \pm 0.2$ vs $0.9 \pm 0.1 ; P \leq 0.05)$. By contrast, the time of anoestrus did not influence the plasma $E_{2}$ and $\mathrm{LH}$ $(P>0.1$; Table 3$)$.

Regarding FSH levels (Table 3), the interaction between the time of anoestrus and progesterone 
Table 3 Follicular populations and basal endocrine levels of FSH, LH and $\mathrm{E}_{2}$ before male introduction (from D-5 to D0) at two times of the seasonal anoestrus (April and June).

\begin{tabular}{|c|c|c|c|c|c|c|c|c|c|}
\hline \multirow[b]{3}{*}{ Progesterone treatment } & \multicolumn{6}{|c|}{ Time of anoestrus } & & & \\
\hline & \multicolumn{2}{|c|}{ Control } & \multicolumn{2}{|c|}{ CIDR2 } & \multicolumn{2}{|c|}{ CIDR12 } & \multicolumn{3}{|c|}{ Two-factor ANOVA } \\
\hline & $\begin{array}{c}\text { April } \\
(n=8)\end{array}$ & $\begin{array}{l}\text { June } \\
(n=8)\end{array}$ & $\begin{array}{c}\text { April } \\
(n=4)\end{array}$ & $\begin{array}{l}\text { June } \\
(n=4)\end{array}$ & $\begin{array}{l}\text { April } \\
(n=4)\end{array}$ & $\begin{array}{l}\text { June } \\
(n=4)\end{array}$ & $\begin{array}{c}\text { Time of } \\
\text { anoestrus }\end{array}$ & $\begin{array}{c}\text { Progesterone } \\
\text { treatment }\end{array}$ & Interaction \\
\hline \multicolumn{10}{|c|}{ Follicular population from D-5 to D0 } \\
\hline Small $(2-3.5 \mathrm{~mm})$ & $9.5 \pm 1.1$ & $10.0 \pm 0.9$ & $9.2 \pm 1.2$ & $10.8 \pm 0.5$ & $10.2 \pm 1.1$ & $9.1 \pm 0.5$ & NS & NS & NS \\
\hline Medium $(3.6-4.5 \mathrm{~mm})$ & $2.3 \pm 0.3$ & $1.8 \pm 0.2$ & $1.8 \pm 0.3$ & $1.9 \pm 0.3$ & $1.7 \pm 0.2$ & $2.3 \pm 0.5$ & NS & NS & NS \\
\hline Large $(\geq 4.6 \mathrm{~mm})$ & $0.9 \pm 0.1$ & $1.8 \pm 0.3$ & $0.9 \pm 0.2$ & $2.0 \pm 0.3$ & $0.9 \pm 0.4$ & $1.0 \pm 0.3$ & $P=0.0040$ & NS & NS \\
\hline Total ( $\geq 2 \mathrm{~mm}$ ) & $12.6 \pm 1.2$ & $13.6 \pm 0.9$ & $11.9 \pm 1.3$ & $14.7 \pm 0.7$ & $12.8 \pm 0.9$ & $12.4 \pm 0.7$ & NS & NS & NS \\
\hline Maximum diameter $(\mathrm{mm})$ & $5.9 \pm 0.2$ & $5.8 \pm 0.1$ & $5.5 \pm 0.2$ & $5.7 \pm 0.1$ & $5.1 \pm 0.3$ & $5.3 \pm 0.1$ & NS & $P=0.0037$ & NS \\
\hline \multicolumn{10}{|c|}{ Mean plasma concentrations from D-5 to D0 } \\
\hline $\mathrm{FSH}(\mathrm{ng} / \mathrm{ml})$ & $0.6 \pm 0.1$ & $0.6 \pm 0.1$ & $0.5 \pm 0.1$ & $0.6 \pm 0.2$ & $1.3 \pm 0.3^{\mathrm{a}}$ & $0.5 \pm 0.1$ & $P=0.0556$ & $P=0.0615$ & $P=0.0076$ \\
\hline $\mathrm{LH}(\mathrm{ng} / \mathrm{ml})$ & $0.4 \pm 0.1$ & $0.6 \pm 0.1$ & $0.4 \pm 0.1$ & $0.4 \pm 0.1$ & $0.3 \pm 0.1$ & $0.4 \pm 0.1$ & NS & NS & NS \\
\hline $\mathrm{E}_{2}(\mathrm{pg} / \mathrm{ml})$ & $0.8 \pm 0.1$ & $1.0 \pm 0.1$ & $1.0 \pm 0.0$ & $0.8 \pm 0.1$ & $0.6 \pm 0.2$ & $0.7 \pm 0.1$ & NS & $P=0.0716$ & NS \\
\hline
\end{tabular}

Values are expressed as arithmetic means \pm s.E.M. $n$, number of ewes; $P$, probability by two-factor ANOVA, followed by multiple comparisons using the Bonferroni's adjustment; NS, not significant with $P>0.10$ (two-factor ANOVA followed by multiple comparisons using the Bonferroni's adjustment). Control, untreated ewes; CIDR2, ewes treated with progesterone for 2 days; CIDR12, ewes treated with progesterone for 12 days. ${ }^{a}$ Significant differences with $P \leq 0.05$ comparing April and June within treatments (two-factor ANOVA followed by multiple comparisons using the Bonferroni's adjustment).

treatment was significant $(P \leq 0.05)$. There was higher FSH plasma levels in the CIDR12 group compared with both CIDR2 and control groups in April, but not in June.

Growth pattern of the preovulatory follicles induced by male effect and endocrine profiles of $F S H, L H$ and $E_{2}$

Overall, 39 preovulatory follicles were identified (one to three per ewe; Fig. 2A). Most of them (37/39) emerged between D-5 and D0, and only two out of 39 ewes (one from CIDR2 ewes and another from CIDR12 ewes) emerged before D-5. At ram introduction, preovulatory follicles had just emerged $(n=9)$ or were in growing $(n=15)$, stationary $(n=10)$ or regressing $(n=5)$ phases. Their size at D0 ranged between 3 and $6.2 \mathrm{~mm}$. Ovulations occurred at a mean follicle diameter of $5.5 \pm 0.1 \mathrm{~mm}$ within 4 days following male exposure.

Superimposed hormonal $\left(\mathrm{FSH}, \mathrm{LH}\right.$ and $\mathrm{E}_{2}$ ) and follicular growth profiles of representative ewes are given in Fig. 3. Before male introduction, plasma FSH, $\mathrm{LH}$ and $\mathrm{E}_{2}$ were at basal levels, even when ovulatory follicles were $\geq 5 \mathrm{~mm}$. Immediately after male introduction, plasma $E_{2}$ increased in all ewes and reached a maximum within $12 \mathrm{~h}$ preceding the $\mathrm{FSH}$ and $\mathrm{LH}$ surges, when the diameter of the preovulatory follicles was close to their ovulatory size.

The influence of the time of anoestrus, progesterone treatment and their interaction were followed on the growth dynamics parameters of the preovulatory follicles (Table 4 and Fig. 2B) and the characteristics of the FSH, $\mathrm{LH}$ and $\mathrm{E}_{2}$ surges (Table 5 ) induced by male effect.

Regarding the effects of progesterone treatment (Table 4), the follicular growth rate decreased $(0.7 \pm 0.1$ vs $1.1 \pm 0.1 \mathrm{~mm} /$ day; $P=0.07)$ and, in parallel, the duration of growth $(4.6 \pm 0.3$ vs $3.0 \pm 0.3$ days,
$P \leq 0.05)$ and the lifespan $(5.9 \pm 0.3$ vs $4.3 \pm 0.3$ days, $P \leq 0.05)$ of preovulatory follicles increased in the ewes from the CIDR12 group compared with the control. The results were intermediary in the CIDR2 group (Table 4 and Fig. 2B). Ovulation was delayed by $\sim 1$ day in the CIDR12 group compared with the control and CIDR2 groups, when ewes were exposed to males in June $(P \leq 0.05)$, but not in April $(P>0.1)$.

Consistent with the effects of progesterone on growth dynamic parameters, the CIDR12 group gave preovulatory $\mathrm{FSH}$ and $\mathrm{LH}$ surges (Table 5) $\sim 10 \mathrm{~h}$ later than control ewes (at $43.0 \pm 4.3$ vs $30.3 \pm 2.6$, and at $42.5 \pm$ 4.5 vs $31.0 \pm 3.2$ h respectively; $P \leq 0.05$ ), whereas these same surges were intermediate in the CIDR2 group $(37.3 \pm 6.5$ and $34.3 \pm 6.2 \mathrm{~h}$ respectively). Moreover, the $\mathrm{AUC}$ of $\mathrm{E}_{2}$ from $\mathrm{D} 0$ to the $\mathrm{LH}$ surge was higher $(P \leq 0.05)$ in the CIDR12 (146 $\pm 18 \mathrm{SAU})$ than the control (95 \pm 7 SAU) and CIDR2 ewes ( $84 \pm 12 \mathrm{SAU})$ as a result of the delay of the $\mathrm{LH}$ surge. The duration and $\mathrm{AUC}$ for the $\mathrm{FSH}$ and $\mathrm{LH}$ surges, and the AUC of $\mathrm{E}_{2}$ within the $12 \mathrm{~h}$ preceding the $\mathrm{LH}$ surge, did not differ between ewes treated or untreated with progesterone $(P>0.1$; Table 5$)$.

In relation to the effects of the time of anoestrus (Table 4), preovulatory follicles of ewes exposed to males in June emerged earlier $(-2.5 \pm 0.3$ vs $-1.1 \pm 0.3$ days; $P \leq 0.05)$, had a greater size at the time of ram introduction $(4.7 \pm 0.2$ vs $4.0 \pm 0.2 \mathrm{~mm} ; P \leq 0.05)$, and attained their maximal size ( $1.1 \pm 0.3$ vs $2.3 \pm 0.2$ days; $P \leq 0.05)$ earlier than in ewes exposed to the male in April, whereas the duration of growth and the lifespan of the preovulatory follicles were similar in April and June $(P>0.1)$. Regarding the ovulation day, the interaction between progesterone treatment and the time of the anoestrus $(P \leq 0.05)$ showed that ewes from control and CIDR2 groups ovulated earlier in June than in April 

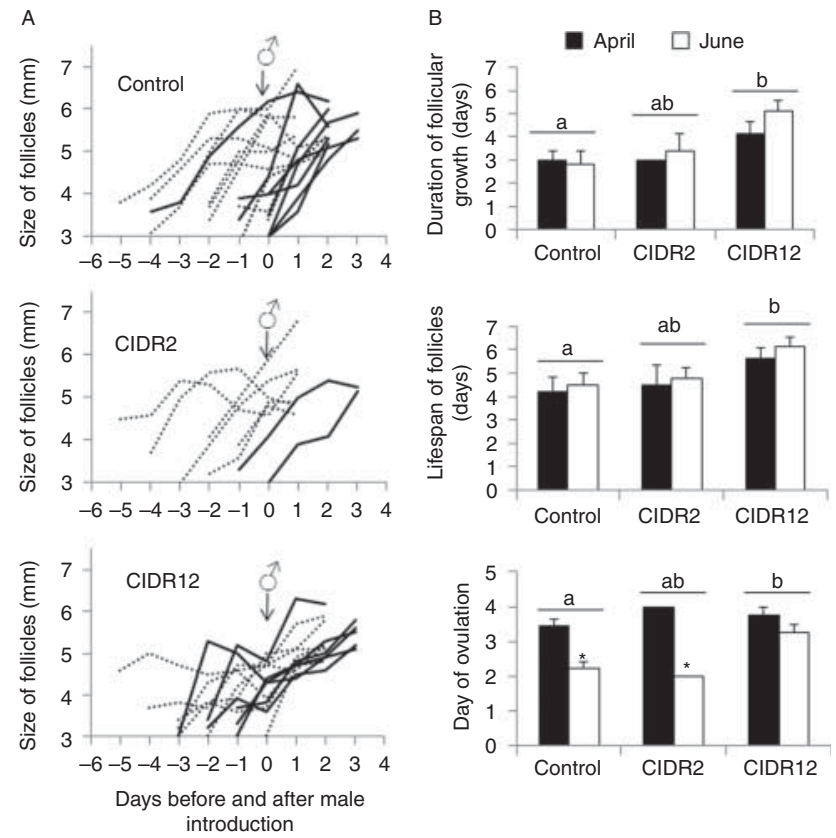

Figure 2 (A) Individual growth profiles of preovulatory follicles induced by the male effect and identified by ultrasonography in untreated ewes (control) and ewes pre-treated with progesterone for 2 (CIDR2) or 12 days (CIDR12) and exposed to males in April (continuous lines) or June (dotted lines). (B) Duration of follicular growth from emergence, lifespan of the preovulatory follicles and day of ovulation observed by ultrasonography in untreated ewes (control) and ewes pre-treated with progesterone for 2 (CIDR2) or 12 days (CIDR12) and exposed to males in April (dark bars) or June (white bars). Values are expressed as mean \pm S.E.M. Different letters ( $a$ and $b$ ) indicate significant differences between treatments (combined data from April and June), with $P \leq 0.05$.

Asterisks $\left(^{*}\right)$ indicate significant differences between April and June within treatments, with $P \leq 0.05$.

$(P \leq 0.05)$, whereas it was similar in the CIDR12 group at both times in the anoestrus season $(P>0.1)$.

In line with the effect of the time of anoestrus on follicular dynamics, the preovulatory surges of FSH and LH occurred $\sim 20 \mathrm{~h}$ earlier in June than in April (26.9 \pm 2.1 vs $44.0 \pm 3.0$ and $25.5 \pm 2.1$ vs $44.5 \pm 2.9 \mathrm{~h}$ respectively; $P \leq 0.05)$ and, consequently, the AUC of $E_{2}$ from Do to the LH surge was higher in April than in June $(120 \pm 11$ vs $85 \pm 7 \mathrm{SAU} ; P \leq 0.05)$. Finally, the AUC of the $\mathrm{FSH}$ surge was higher in June than in April $(6.8 \pm 0.8$ vs $3.2 \pm 0.4 \mathrm{SAU} ; P \leq 0.05$ ), whereas the duration of the $\mathrm{LH}$ and $\mathrm{FSH}$ surges, the AUC of the $\mathrm{LH}$ surge and the AUC $-\mathrm{E}_{2}$ within $12 \mathrm{~h}$ before the $\mathrm{LH}$ surge were similar at both times in the anoestrus season ( $P>0.1$; Table 5$)$.

\section{Experiment 2: effect of the length of progesterone treatment on follicular maturation following male exposure}

\section{Oestrous behaviour, ovulation and quality of cycle}

Most of the ewes that were not slaughtered (25/30; 83\%) had a $\mathrm{LH}$ surge within $40 \mathrm{~h}$ following male exposure and then ovulated (as confirmed by measuring plasma progesterone profiles). The $\mathrm{LH}$ surge occurred at $21.6 \pm 1.6,21.5 \pm 2.1$ and $28.0 \pm 1.0 \mathrm{~h}$ in the control, CIDR2 and CIDR12 ewes respectively. Ovulating ewes from CIDR2 (8/10) and CIDR12 (9/10) groups developed a normal cycle. Ovulating control ewes (8/10) developed both normal $(n=4)$ and short cycles $(n=4)$. Oestrous behaviour occurred in all ewes from the CIDR12 group. No ewes of the control and CIDR2 groups were in oestrus.

\section{Intra-follicular hormonal analysis and} gene expression of granulosa and theca cells

Of the 30 slaughtered ewes, five were excluded from the analysis because they had either a corpus luteum before ram introduction (as observed by ultrasonography of ovaries; two ewes) or an LH surge before slaughtering (three ewes).
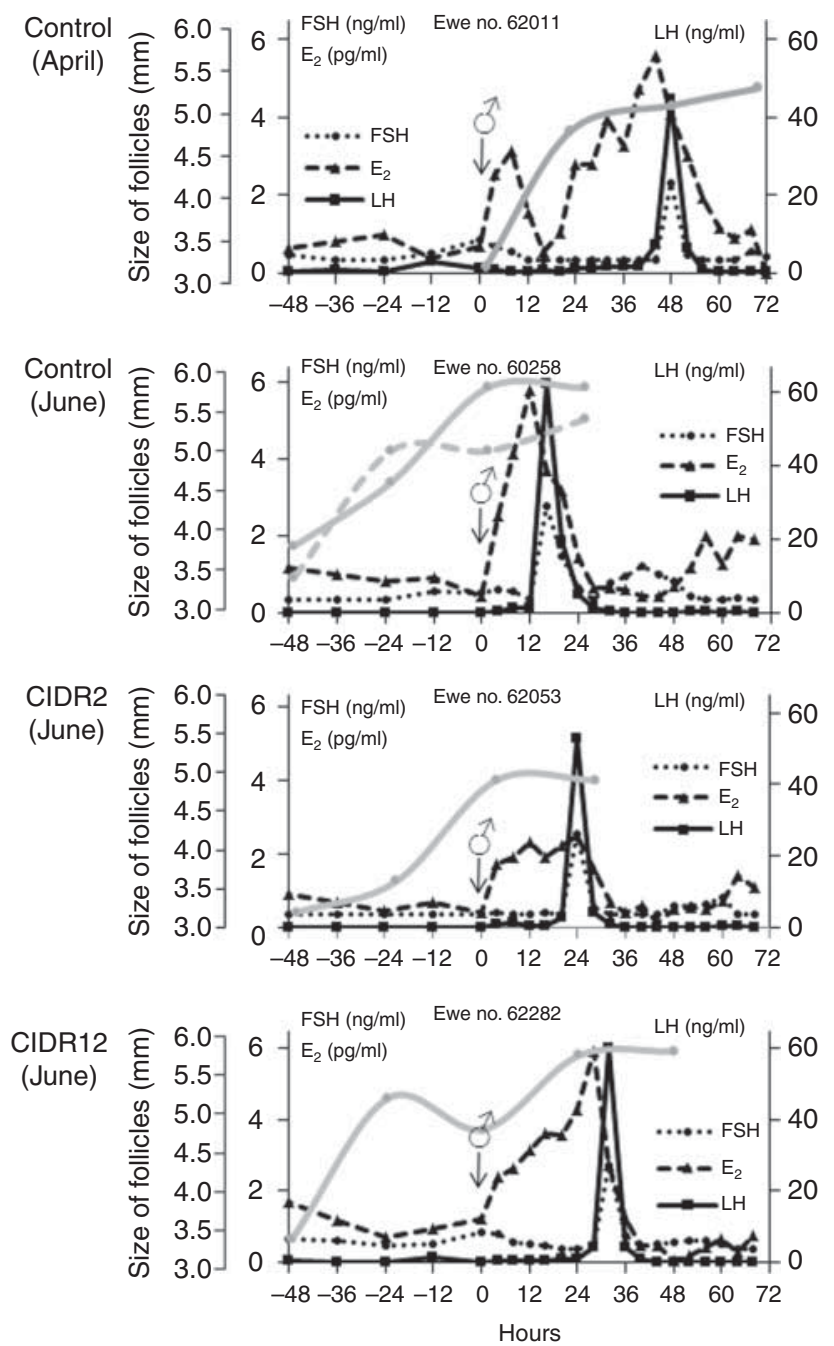

Figure 3 Superimposed endocrine $\left(\mathrm{FSH}, \mathrm{LH}\right.$ and $\left.\mathrm{E}_{2}\right)$ and follicular growth (grey arrows) profiles of representative untreated ewes (control) and ewes pre-treated with progesterone for 2 (CIDR2) or 12 days (CIDR12) before exposure to males in April or June. 
Table 4 Growth dynamics of the preovulatory follicles induced by male effect and identified by ultrasonography (from D-5 to D7) at two times of the seasonal anoestrus (April and June).

\begin{tabular}{|c|c|c|c|c|c|c|c|c|c|}
\hline \multirow[b]{3}{*}{$\begin{array}{l}\text { Progesterone } \\
\text { treatment }\end{array}$} & \multicolumn{6}{|c|}{ Time of anoestrus } & & & \\
\hline & \multicolumn{2}{|c|}{ Control } & \multicolumn{2}{|c|}{ CIDR2 } & \multicolumn{2}{|c|}{ CIDR12 } & \multicolumn{3}{|c|}{ Two-factor ANOVA } \\
\hline & $\begin{array}{c}\text { April } \\
(n=7)^{\mathrm{a}}\end{array}$ & $\begin{array}{l}\text { June } \\
(n=7)^{\mathrm{a}}\end{array}$ & $\begin{array}{c}\text { April } \\
(n=2)^{\mathrm{a}}\end{array}$ & $\begin{array}{l}\text { June } \\
(n=4)\end{array}$ & $\begin{array}{l}\text { April } \\
(n=4)\end{array}$ & $\begin{array}{l}\text { June } \\
(n=4)\end{array}$ & $\begin{array}{c}\text { Time of } \\
\text { anoestrus }\end{array}$ & $\begin{array}{c}\text { Progesterone } \\
\text { treatment }\end{array}$ & Interaction \\
\hline $\begin{array}{l}\text { Day of } \\
\text { emergence }\end{array}$ & $-0.8 \pm 0.6$ & $-2.2 \pm 0.6$ & $-0.5 \pm 0.5$ & $-2.8 \pm 0.6$ & $-1.9 \pm 0.3$ & $-2.9 \pm 0.3$ & $P=0.0074$ & NS & NS \\
\hline Size at D0 (mm) & $3.9 \pm 0.4$ & $4.8 \pm 0.4$ & $3.6 \pm 0.6$ & $5.2 \pm 0.2$ & $4.3 \pm 0.2$ & $4.3 \pm 0.3$ & $P=0.0259$ & NS & NS \\
\hline $\begin{array}{l}\text { Day of maximum } \\
\text { size (end of } \\
\text { growth) }\end{array}$ & $2.2 \pm 0.3$ & $0.7 \pm 0.5$ & $2.5 \pm 0.5$ & $0.6 \pm 0.4$ & $2.3 \pm 0.5$ & $2.3 \pm 0.3$ & $P=0.0070$ & NS & NS \\
\hline Ovulatory size (mm) & $5.6 \pm 0.2$ & $5.5 \pm 0.3$ & $5.2 \pm 0.0$ & $5.5 \pm 0.5$ & $5.6 \pm 0.2$ & $5.3 \pm 0.1$ & NS & NS & NS \\
\hline Day of ovulation & $3.4 \pm 0.2$ & $2.2 \pm 0.2^{\mathrm{b}}$ & $4.0 \pm 0.0$ & $2.0 \pm 0.0^{\mathrm{b}}$ & $3.8 \pm 0.3$ & $3.3 \pm 0.3$ & $P<0.0001$ & $P=0.0089$ & $P=0.0202$ \\
\hline $\begin{array}{l}\text { Duration of growth } \\
\text { (days) }\end{array}$ & $3.0 \pm 0.4$ & $2.9 \pm 0.5$ & $3.0 \pm 0.0$ & $3.4 \pm 0.8$ & $4.1 \pm 0.5$ & $5.1 \pm 0.4$ & NS & $P=0.0117$ & NS \\
\hline $\begin{array}{l}\text { Follicular growth } \\
\text { rate }(\mathrm{mm} / \text { day })\end{array}$ & $1.0 \pm 0.1$ & $1.1 \pm 0.2$ & $0.8 \pm 0.1$ & $1.0 \pm 0.2$ & $0.8 \pm 0.2$ & $0.5 \pm 0.1$ & NS & $P=0.0660$ & NS \\
\hline $\begin{array}{l}\text { Lifespan of } \\
\text { preovulatory } \\
\text { follicles (days) }\end{array}$ & $4.2 \pm 0.5$ & $4.5 \pm 0.6$ & $4.5 \pm 0.5$ & $4.8 \pm 0.6$ & $5.6 \pm 0.4$ & $6.1 \pm 0.4$ & NS & $P=0.0381$ & NS \\
\hline $\begin{array}{l}\text { Number of } \\
\text { ovulations }\end{array}$ & $1.1 \pm 0.1$ & $1.4 \pm 0.3$ & $1.0 \pm 0.0$ & $1.5 \pm 0.3$ & $1.5 \pm 0.3$ & $1.7 \pm 0.2$ & NS & NS & NS \\
\hline
\end{tabular}

Values are expressed as arithmetic means \pm S.E.M. $n$, number of ewes; $P$, probability by two-factor ANOVA followed by multiple comparisons using the Bonferroni's adjustment (NS, not significant with $P>0.10$ ). Control: untreated ewes; CIDR2, ewes treated with progesterone for 2 days; CIDR12, ewes treated with progesterone for 12 days.

${ }^{a}$ Three ewes (two of the control and one of the CIDR2 groups) were excluded from the analysis because ultrasound scanning images were doubtful, and one or more parameters could not be determined, with one ewe of the CIDR2 group not ovulating in April. ${ }^{b}$ Significant differences with $P \leq 0.05$ comparing April and June within treatments (two-factor ANOVA, followed by multiple comparisons using the Bonferroni's adjustment).

A total of 40 healthy (non-atretic) follicles $\geq 5 \mathrm{~mm}$ were collected $7.6 \pm 1.6,5.5 \pm 2.1$ and $6.0 \pm 1.0 \mathrm{~h}$ before the expected LH surge (the 'reference' time of LH surge being the one in ewes that were not slaughtered) from control (seven ewes and 11 follicles), CIDR2 (nine ewes and 16 follicles) and CIDR12 ewes (nine ewes and 13 follicles) respectively. Extraction products from 12 follicles were not analysed by RT-PCR due to the low amount of the RNA extracted.

Intra-follicular $\mathrm{E}_{2}$ was higher in ewes from the CIDR2 and CIDR12 groups than those from the control group $\left(P \leq 0.05\right.$; Fig. 4A). $E_{2}$ concentrations were also positively correlated $(r=0.55, P \leq 0.05)$ with those of progesterone, which tended to increase $(P=0.09)$ in the CIDR12 group (Fig. 4A).

Regarding the expression of functional markers in granulosa cells, mRNA expression of FSHR, CYP19A1, CYP11A1, INHA and VEGFA did not differ between groups of ewes treated or untreated with progesterone $(P>0.1$; Fig. 4B). By contrast, mRNA levels of LHCGR and STAR were higher in the progesterone-treated groups than the control one $(P \leq 0.05$; Fig. 4B). Intrafollicular $\mathrm{E}_{2}$ was positively correlated $(P \leq 0.05)$ with the mRNA levels of LHCGR $(r=0.54)$ and STAR $(r=0.54)$. The mRNA levels of $L H C G R$ were positively correlated $(P \leq 0.05)$ with those of STAR $(r=0.41)$, CYP19A1 $(r=0.75)$ and $F S H R(r=0.54)$.

In the theca cells, mRNA levels of LHCGR, STAR, CYP11A1 and CYP17A1 were higher in the CIDR12 group compared with the control group $(P \leq 0.05$; Fig. 4C); results in the CIDR2 group were intermediary. By contrast, no differences between groups were observed regarding mRNA expression of VEGFA $(P>0.1$; Fig. $4 \mathrm{C})$. Intra-follicular $\mathrm{E}_{2}$ concentration was positively correlated $(P \leq 0.05)$ with the mRNA levels of STAR $(r=0.65)$, CYP11A1 $(r=0.54)$ and CYP17A1 $(r=0.42)$ in theca cells. Moreover, mRNA levels of $L H C G R$ in theca cells were highly and positively correlated $(P \leq 0.05)$ with those of STAR $(r=0.50)$, CYP11A1 $(r=0.72)$ and CYP17A1 $(r=0.77)$ in these cells.

\section{Discussion}

Progesterone priming acts on the hypothalamicpituitary-gonadal axis by improving the completion of growth and maturation of preovulatory follicles induced by the male effect in anovulatory ewes outside the breeding season. Indeed, our results show that a long-term progesterone treatment (mimicking a normal luteal phase of 12 days) can increase the duration of growth and lifespan of preovulatory follicles induced by the male effect up to a mean duration of 4.5 and 6.0 days, respectively, similar to those in the breeding season (Evans 2003). Healthy large follicles (potential preovulatory follicles) recovered within $12 \mathrm{~h}$ preceding the LH surge from ewes pre-treated with progesterone for 12 days and also had an increase in intra-follicular 
Table 5 Characteristics of the pre-ovulatory surges of $\mathrm{FSH}, \mathrm{LH}$ and $\mathrm{E}_{2}$ induced by male effect at two times of the seasonal anoestrus (April and June).

\begin{tabular}{|c|c|c|c|c|c|c|c|c|c|}
\hline \multirow[b]{3}{*}{$\begin{array}{l}\text { Progesterone } \\
\text { treatment } \\
\end{array}$} & \multicolumn{6}{|c|}{ Time of anoestrus } & & & \\
\hline & \multicolumn{2}{|c|}{ Control } & \multicolumn{2}{|c|}{ CIDR2 } & \multicolumn{2}{|c|}{ CIDR12 } & \multicolumn{3}{|c|}{ Two-factor ANOVA } \\
\hline & $\begin{array}{c}\text { April } \\
(n=8)\end{array}$ & $\begin{array}{l}\text { June } \\
(n=8)\end{array}$ & $\begin{array}{c}\text { April } \\
(n=3)^{\mathrm{a}}\end{array}$ & $\begin{array}{l}\text { June } \\
(n=4)\end{array}$ & $\begin{array}{c}\text { April } \\
(n=4)\end{array}$ & $\begin{array}{l}\text { June } \\
(n=4)\end{array}$ & $\begin{array}{c}\text { Time of } \\
\text { anoestrus }\end{array}$ & $\begin{array}{c}\text { Progesterone } \\
\text { treatment }\end{array}$ & Interaction \\
\hline $\begin{array}{l}\text { Time of the } \\
\text { FSH surge (h) }\end{array}$ & $37.1 \pm 2.9$ & $23.4 \pm 3.1$ & $50.7 \pm 7.1$ & $24.0 \pm 4.6^{b}$ & $51.0 \pm 6.4$ & $35.0 \pm 1.9$ & $P<0.0001$ & $P=0.0116$ & NS \\
\hline $\begin{array}{l}\text { Time of the } \\
\text { LH surge }(h)\end{array}$ & $39.5 \pm 4.0$ & $22.5 \pm 2.6^{\mathrm{b}}$ & $49.3 \pm 7.4$ & $23.0 \pm 2.5^{\mathrm{b}}$ & $51.0 \pm 6.4$ & $34.0 \pm 2.5$ & $P<0.0001$ & $P=0.0300$ & NS \\
\hline $\begin{array}{l}\text { Duration of the } \\
\text { FSH surge }(h)\end{array}$ & $5.7 \pm 0.7$ & $7.2 \pm 0.8$ & $7.6 \pm 0.5$ & $8.6 \pm 1.3$ & $6.9 \pm 0.7$ & $6.9 \pm 0.5$ & NS & NS & NS \\
\hline Duration of the LH surge $(\mathrm{h})$ & $13.8 \pm 0.6$ & $16.6 \pm 1.1$ & $16.2 \pm 0.5$ & $20.6 \pm 6.4$ & $14.2 \pm 1.7$ & $13.4 \pm 0.9$ & NS & NS & NS \\
\hline $\begin{array}{l}\text { AUC-FSH under the } \\
\text { surge (SAU) }\end{array}$ & $2.7 \pm 0.6$ & $7.1 \pm 1.4^{b}$ & $2.8 \pm 0.5$ & $6.9 \pm 1.5$ & $4.5 \pm 0.7$ & $6.2 \pm 0.9$ & $P=0.0023$ & NS & NS \\
\hline $\begin{array}{l}\text { AUC-LH under the } \\
\text { surge (SAU) }\end{array}$ & $215.9 \pm 7.3$ & $284.2 \pm 26.3$ & $283.9 \pm 35.2$ & $212.8 \pm 33.7$ & $230.7 \pm 24.9$ & $260 \pm 17.5$ & NS & NS & $P=0.0528$ \\
\hline $\begin{array}{l}A \cup C-E_{2} \text { from } \\
\text { D0 to the } \\
\text { LH surge (SAU) }\end{array}$ & $107.1 \pm 10.7$ & $82.6 \pm 8.4$ & $93.2 \pm 6.6$ & $77.5 \pm 21.4$ & $165.5 \pm 20.4$ & $106.5 \pm 6.0$ & $P=0.0183$ & $P=0.0161$ & NS \\
\hline $\begin{array}{l}\text { AUC- } E_{2} \text { within } 12 \mathrm{~h} \\
\text { before the } \mathrm{LH} \\
\text { surge (SAU) }\end{array}$ & $42.1 \pm 5.9$ & $45.4 \pm 3.6$ & $33.6 \pm 4.9$ & $43.1 \pm 9.2$ & $52.5 \pm 3.7$ & $44.2 \pm 8.1$ & NS & NS & NS \\
\hline
\end{tabular}

Values are expressed as arithmetic means \pm s.E.M. $n$, number of ewes; SAU, surface arbitrary unit; $P$, probability by two-factor ANOVA followed by multiple comparisons using the Bonferroni's adjustment (NS, not significant with $P>0.10$ ). Control, untreated ewes; CIDR2, ewes treated with progesterone for 2 days; CIDR12, ewes treated with progesterone for 12 days.

${ }^{a}$ One ewe of the CIDR2 group did not ovulate in April. ${ }^{b}$ Significant differences with $P \leq 0.05$ comparing April and June within treatments (two-factor ANOVA, followed by multiple comparisons using the Bonferroni's adjustment).

$E_{2}$ concentrations, as well as in the expression of genes encoding LH receptor and STAR in both granulosa and theca cells. In parallel, the expression of genes involved in the biosynthesis of progesterone and androgens (CYP11A1 and CYP17A1) also increased in theca cells. These results were dependent on the duration of exposure to progesterone, with 2 days (short term) of progesterone treatment giving intermediate results in general.

The mechanisms by which progesterone priming manages follicular growth and lifespan of ovulatory waves induced by male effect remain unclear. In cyclic ewes treated with progestagens, prolongation of the lifespan of ovulatory follicles has been associated with the advancement of follicle emergence (Vinoles et al. 2001), whereas this was related to both the advancement of follicle emergence and a delay in ovulation during seasonal anoestrus (Leyva et al. 1998, Ungerfeld \& Rubianes 1999). According to these reports, the longer growth and lifespan of preovulatory follicles in the ewes treated with progesterone were mainly related to a decreased growth rate and led to delayed LH surge and ovulation in our experiments. The emergence of ovulatory follicles advanced by $\sim 1$ day in progesteroneprimed ewes, although this difference was not confirmed statistically.

Two non-exclusive hypotheses could explain these results on follicular dynamics. First, the delay of the LH surge could be explained by the presence of residual progesterone in the blood at the time of ram introduction, as suggested in a previous study (Pearce \& Oldham 1984). However, this hypothesis can be rejected because progesterone is cleared within a few hours after removal of the implants (Skinner et al. 1998, Van Cleeff et al. 1998), and we have shown that CIDR was removed $24 \mathrm{~h}$ before the start of the stimulation by ram. Besides, hormonal assay in blood samples clearly indicated that progesterone had completely cleared before male introduction. Secondly, the differences found in our study might be due to exposure of the gonadotrophin-releasing hormone $(\mathrm{GnRH})$ system to powerful inhibitory effect of progesterone (Caraty \& Skinner 1999). According to this hypothesis, following CIDR removal, the response of the hypothalamuspituitary axis to the stimulatory signals of males might be delayed, resulting in a slow follicular growth rate and a late LH surge. In support of this hypothesis, diminution in the maximum diameter of follicles and decrease in plasma $E_{2}$ observed in our study during the period preceding male introduction in the ewes treated with progesterone are consistent with a lower frequency of pulsatile GnRH secretion and of LH (Hauger et al. 1977). In addition, the inhibitory effect of progesterone on the frequency of pulsatile $\mathrm{GnRH}$ secretion could be strengthened early, rather than later, in the anoestrus when steroids' access to the brain is enhanced (Thiery \& Malpaux 2003). This could explain how basal FSH concentrations increase in the CIDR12 group in April compared with June. Nevertheless, more investigation is required concerning the characterisation of pulsatile 

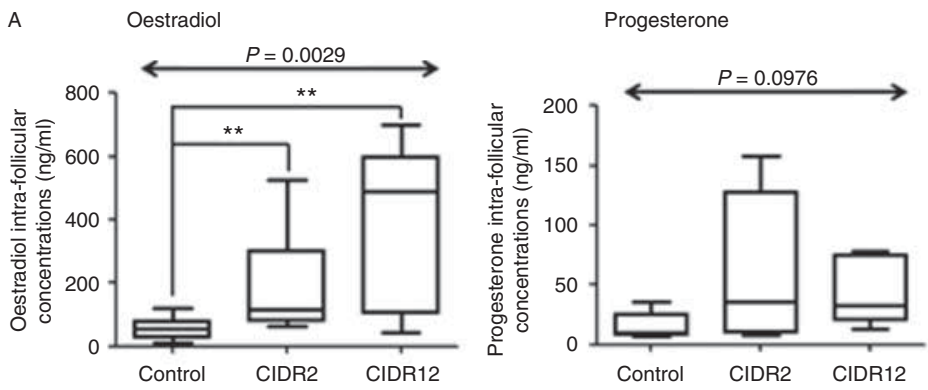

B
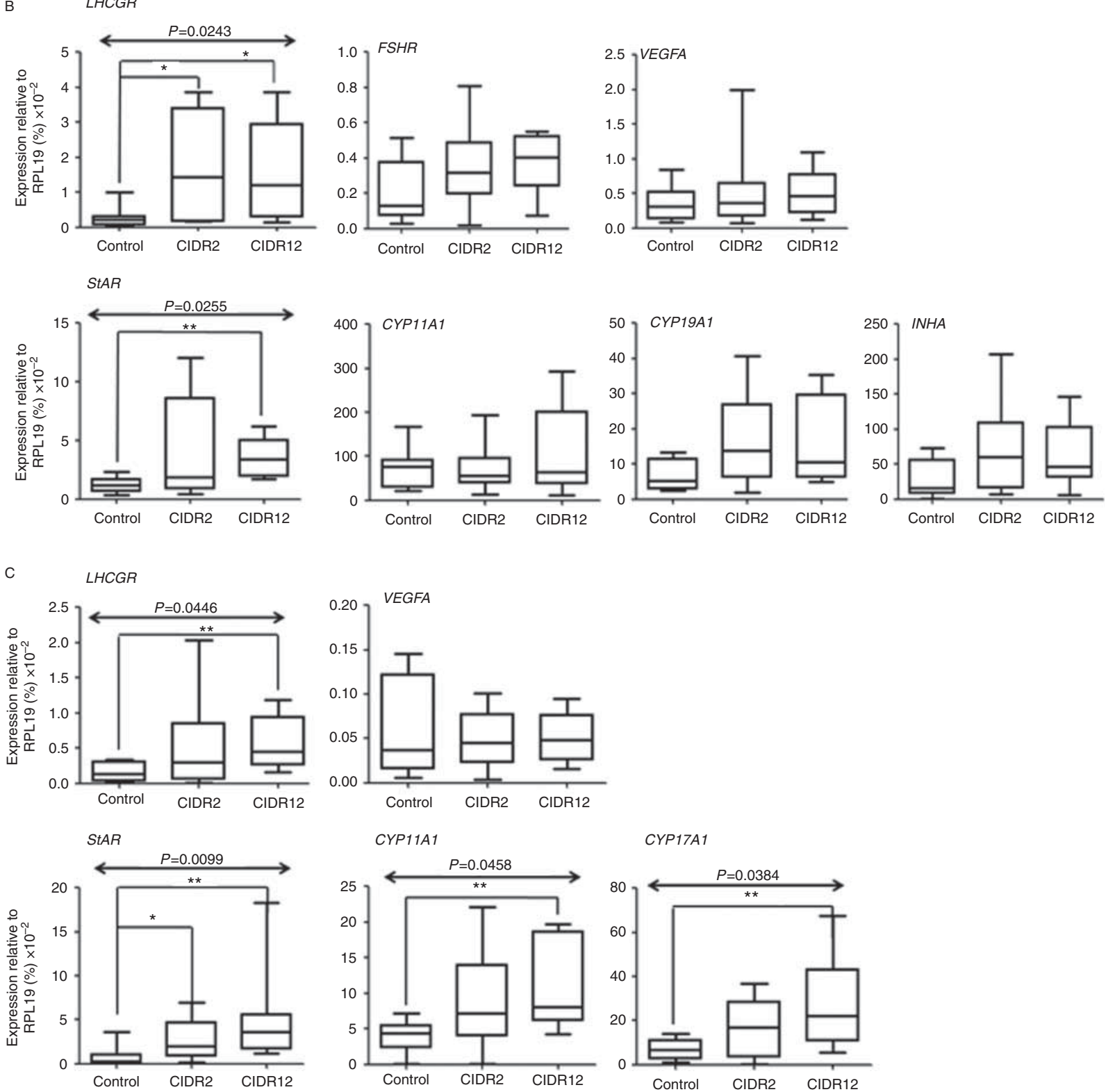

\section{CYP17A1}

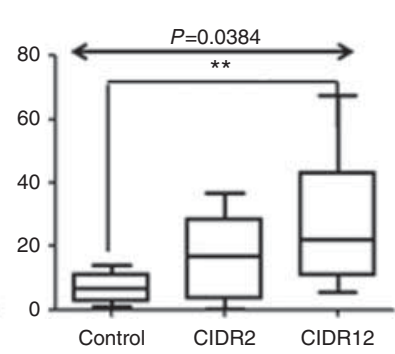

Figure 4 Intra-follicular oestradiol and progesterone concentrations (A), and mRNA expression (relative to that of the reference gene RPL19) of follicular maturation markers in granulosa (B) and theca (C) cells recovered from healthy follicles with a diameter of $\geq 5 \mathrm{~mm}$ collected within $12 \mathrm{~h}$ preceding the LH surge from untreated ewes (control) or ewes pre-treated with progesterone for 2 (CIDR2) or 12 days (CIDR12) before exposure to males in June. Data are expressed as median \pm interquartile. $P=$ probability by the Kruskal-Wallis test. Asterisks indicate the probability following two-sample comparison by the Mann-Whitney-Wilcoxon test $\left({ }^{*} P \leq 0.05\right.$ and $\left.{ }^{*} P \leq 0.01\right)$. 
$\mathrm{GnRH}$ and $\mathrm{LH}$ secretions in progesterone-primed ewes exposed to males.

Moreover, in the first experiment, only two out of 16 control ewes developed a normal cycle. For that reason, no conclusion can be drawn about the follicular dynamic mechanisms involved in the development of normal cycles without progesterone priming. Further studies are therefore required to elucidate this phenomenon.

Our results indicate that progesterone priming can improve the steroidogenic activity of the male-induced preovulatory follicles. Taking into account that the expression of CYP19A1 mRNA in granulosa cells was not influenced by progesterone priming, the higher intra-follicular $E_{2}$ levels observed in progesteronetreated ewes would probably be the result of an increased production of androgenic substrate by $\mathrm{LH}$-stimulated theca cells, enabling the follicle to produce more $E_{2}$ in granulosa cells (Young \& McNeilly 2010). This hypothesis is supported by the concomitant increase in gene expression of STAR, encoding a protein which facilitates the transfer of cholesterol to the mitochondrial inner membrane, and of CYP11A1 and CYP17A1, encoding enzymes involved in the biosynthesis of progesterone and androgens ( $\mathrm{Li}$ et al. 2009), that we observed in the theca cells of progesterone-treated ewes. Moreover, the increased mRNA expression of $\mathrm{LH}$ receptors in the granulosa and theca cells of progesterone-treated ewes suggests that progesterone priming could also enhance the ability of follicular cells to respond to $\mathrm{LH}$, reinforcing by this way the stimulating effect of LH on steroidogenesis (Magoffin \& Weitsman 1993, Lavoie \& King 2009). However, further research is necessary to examine whether all these mRNA changes are associated with the modifications in the protein expression levels in follicular cells.

Vascular and angiogenic growth factors are essential for follicular development and luteal outcome. Recent findings have shown that progesterone ensures adequate luteal function by increasing the expression of angiogenic factors (such as the vascular endothelial growth factor A (VEGFA) and its receptor KDR (VEGFR2) in both theca and granulosa cells of seasonal anoestrous ewes when ovulation is induced by $\mathrm{GnRH}$ (Christensen et al. 2014). Nevertheless, in our experiment, we found no difference in the mRNA expression of VEGFA between ewes treated and not treated with progesterone. The method used to induce ovulation (GnRH vs male effect) and/or the studied follicular population $(\mathrm{GnRH}$-induced antral follicles $\geq 2.5 \mathrm{~mm}$ vs male-induced preovulatory follicles $\geq 5 \mathrm{~mm}$ ) could account for this discrepancy. Assessment of the VEGFA expression profile in maleinduced preovulatory follicles during and after the LH surge in both granulosa and theca cells should be investigated.

Finally, the absence of changes mediated by progesterone priming in mRNA expression of FSHR and
INHA in granulosa cells suggests that these functional markers are not significantly involved in the mechanism of action by which progesterone improves follicular maturation. Nevertheless, it should be noticed that, in the second experiment, some control ewes from the experimental group could be able to develop normal cycles (as observed for some control ewes from the notslaughtered monitoring group). In this case, they could have a follicular maturation pattern similar to that observed in progesterone-treated ewes, hence reducing the possibility to detect the differences between groups in the expression of genes involved, to a less extent, in the development of short cycles.

Independent of progesterone treatment, our results indicate that the time of the seasonal anoestrus affects the ovarian follicular population and the dynamics of the male-induced preovulatory follicles. Indeed, when approaching the breeding season, the $E_{2}$ negative feedback on the hypothalamus-pituitary axis is weaker, ovarian responsiveness to gonadotrophins increases (Legan et al. 1985b) and the incidence of atresia decreases (Cahill et al. 1984). This could explain, as reported previously (Pellicer-Rubio et al. 2012), as to why there is a greater number of large follicles before the introduction of rams in June than in April. Besides, an increase in the lifespan of the largest follicles of sequential waves, and in the duration of their regressing phases throughout the seasonal anoestrus, has been reported (Bartlewski et al. 2000). These findings suggest that the antral follicles selected at ram introduction in June in our study could have developed in follicular waves with longer lifespan and regressing phases compared with those selected in April. As a consequence, the time during which large follicles are responsive to the male effect is extended, thus increasing the probability for these follicles being selected at ram introduction. This situation could explain as to why the selected follicles during the late anoestrus emerged earlier, had reached a larger diameter and a more advanced state of maturation at the time of male exposure and, consequently, ovulated shortly afterwards.

In conclusion, first, this study demonstrates that progesterone priming can improve luteal function by controlling follicular dynamics and enhancing the steroidogenic activity of preovulatory follicles induced by the male effect. More work is required to see whether these changes have functional consequences on the quality of oocytes and to investigate the fertility of the first ovulation induced by male effect in seasonal anoestrous ewes, in order to promote artificial insemination. Secondly, this study provides some evidence indicating that ewes exposed to males ovulate earlier when approaching the breeding season due to the selection, at the time of ram introduction, of follicles in a more advanced stage of development without changing the duration of their growth and lifespan. However, these effects are unrelated to luteal outcome. 


\section{Declaration of interest}

The authors declare that there is no conflict of interest that could be perceived as prejudicing the impartiality of the research reported.

\section{Funding}

This research did not receive any specific grant from any funding agency in the public, commercial or not-for-profit sector. A Adib's PhD grant was funded by INRA and the French 'Région Centre'.

\section{Acknowledgements}

The authors thank Philippe Chemineau and Hugues Dardente for their contribution to this manuscript. They extend their thanks to the INRA Experimental Unit of Animal Physiology (Nouzilly, France) for providing animals and the INRA hormonal assay laboratory (Nouzilly, France) for their collaboration. The English revision of this manuscript was assisted by BioMedES (Scotland, UK).

\section{References}

Abdennebi L, Lesport AS, Remy JJ, Grebert D, Pisselet C, Monniaux D \& Salesse R 2002 Differences in splicing of mRNA encoding LH receptor in theca cells according to breeding season in ewes. Reproduction 123 819-826. (doi:10.1530/rep.0.1230819)

Bacich DJ, Rohan RM, Norman RJ \& Rodgers RJ 1994 Characterization and relative abundance of alternatively spliced luteinizing hormone receptor messenger ribonucleic acid in the ovine ovary. Endocrinology 135 735-744. (doi:10.1210/endo.135.2.8033821)

Bartlewski PM, Vanderpol J, Beard AP, Cook SJ \& Rawlings NC 2000 Ovarian antral follicular dynamics and their associations with peripheral concentrations of gonadotropins and ovarian steroids in anoestrous Finnish Landrace ewes. Animal Reproduction Science 58 273-291. (doi:10.1016/S0378-4320(99)00092-5)

Bartlewski PM, Beard AP, Chapman CL, Nelson ML, Palmer B, Aravindakshan J, Cook S] \& Rawlings NC 2001 Ovarian responses in gonadotrophin-releasing hormone-treated anoestrous ewes: follicular and endocrine correlates with luteal outcome. Reproduction, Fertility, and Development 13 133-142. (doi:10.1071/RD00092)

Ben Said S, Lomet D, Chesneau D, Lardic L, Canepa S, Guillaume D, Briant C, Fabre-Nys C \& Caraty A 2007 Differential estradiol requirement for the induction of estrus behavior and the luteinizing hormone surge in two breeds of sheep. Biology of Reproduction $\mathbf{7 6}$ 673-680. (doi:10.1095/biolreprod.106.057406)

Brown HM, Fabre Nys C, Cognie J \& Scaramuzzi RJ 2014 Short oestrous cycles in sheep during anoestrus involve defects in progesterone biosynthesis and luteal neovascularisation. Reproduction 147 357-367. (doi:10.1530/REP-13-0400)

Cahill LP, Oldham CM, Cognie Y, Ravault JP \& Mauleon P 1984 Season and photoperiod effects on follicles and atresia in sheep ovary. Australian Journal of Biological Science 37 71-77. (doi:10.1071/B19840071)

Canepa S, Laine AL, Bluteau A, Fagu C, Flon C \& Monniaux D 2008 Validation d'une methode immunoenzymatique pour le dosage de la progesterone dans le plasma des ovins et des bovins. Cahiers Techniques de I'INRA 64 19-30.

Caraty A \& Skinner DC 1999 Progesterone priming is essential for the full expression of the positive feedback effect of estradiol in inducing the preovulatory gonadotropin-releasing hormone surge in the ewe. Endocrinology 140 165-170. (doi:10.1210/endo.140.1.6444)
Chanvallon A, Sagot L, Pottier E, Debus N, Francois D, Fassier T, Scaramuzzi RJ \& Fabre-Nys C 2011 New insights into the influence of breed and time of the year on the response of ewes to the 'ram effect'. Animal 5 1594-1604. (doi:10.1017/S1751731111000668)

Chemineau P, Malpaux B, Delgadillo JA, Guérin Y, Ravault JP, Thimonier J \& Pelletier J 1992 Control of sheep and goats reproduction: use of light and melatonin. Animal Reproduction Science 30 157-184. (doi:10.1016/0378-4320(92)90010-B)

Chemineau P, Pellicer-Rubio MT, Lassoued N, Khaldi G \& Monniaux D 2006 Male-induced short oestrous and ovarian cycles in sheep and goats: a working hypothesis. Reproduction, Nutrition, Development $\mathbf{4 6}$ 417-429. (doi:10.1051/rnd:2006022)

Christensen AC, Haresign W \& Khalid M 2014 Progesterone exposure of seasonally anoestrous ewes alters the expression of angiogenic growth factors in preovulatory follicles. Theriogenology $\mathbf{8 1}$ 358-367. (doi:10.1016/j.theriogenology.2013.10.005)

Cognié Y, Gray SJ, Lindsay DR, Oldham CM, Pearce DT \& Signoret JP 1982 A new approach to controlled breeding in sheep using the "ram effect". Proceedings of the Australian Society for Animal Production 14 519-522.

Duggavathi R, Bartlewski PM, Barrett DM \& Rawlings NC 2003 Use of high-resolution transrectal ultrasonography to assess changes in numbers of small ovarian antral follicles and their relationships to the emergence of follicular waves in cyclic ewes. Theriogenology 60 495-510. (doi:10. 1016/S0093-691X(03)00041-4)

Evans AC 2003 Ovarian follicle growth and consequences for fertility in sheep. Animal Reproduction Science 78 289-306. (doi:10.1016/S03784320(03)00096-4)

Fabre-Nys C \& Gelez H 2007 Sexual behavior in ewes and other domestic ruminants. Hormones and Behavior 52 18-25. (doi:10.1016/j.yhbeh. 2007.04.001)

Faure MO, Nicol L, Fabre S, Fontaine J, Mohoric N, McNeilly A \& Taragnat C 2005 BMP-4 inhibits follicle-stimulating hormone secretion in ewe pituitary. Journal of Endocrinology 186 109-121. (doi:10.1677/ joe.1.05988)

Hauger RL, Karsch FJ \& Foster DL 1977 A new concept for control of the estrous cycle of the ewe based on the temporal relationships between luteinizing hormone, estradiol and progesterone in peripheral serum and evidence that progesterone inhibits tonic LH secretion. Endocrinology 101 807-817. (doi:10.1210/endo-101-3-807)

Hunter MG, Southee JA, McLeod BJ \& Haresign W 1986 Progesterone pretreatment has a direct effect on GnRH-induced preovulatory follicles to determine their ability to develop into normal corpora lutea in anoestrous ewes. Journal of Reproduction and Fertility 76 349-363. (doi:10.1530/jrf.0.0760349)

Lardic L, Scaramuzzi RJ, Dupont J, Gauthier J \& Fabre Nys C 2012 Amélioration de la sensibilité du kit ELISA DIASOURCE pour le dosage de l'oestradiol-17 $\beta$ dans le plasma ovin. Journées Internationales de Biologie. Paris 7-8 novembre 2012, Poster $n^{\circ} 7$ p: 67-68. (www.jib-sdbio.fr)

Lassoued N, Khaldi G, Chemineau P, Cognie Y \& Thimonier J 1997 Role of the uterus in early regression of corpora lutea induced by the ram effect in seasonally anoestrous Barbarine ewes. Reproduction, Nutrition, Development 37 559-571. (doi:10.1051/rnd:19970507)

Lavoie HA \& King SR 2009 Transcriptional regulation of steroidogenic genes: STARD1, CYP11A1 and HSD3B. Experimental Biology and Medicine 234 880-907. (doi:10.3181/0903-MR-97)

Legan SJ, I'Anson H, Fitzgerald BP \& Akaydin MS Jr 1985a Importance of short luteal phases in the endocrine mechanism controlling initiation of estrous cycles in anestrous ewes. Endocrinology 117 1530-1536. (doi:10.1210/endo-117-4-1530)

Legan SJ, Goodman RL, Ryan KD, Foster DL \& Karsch FJ 1985b Can the transition into anoestrus in the ewe be accounted for solely by insufficient tonic LH secretion? Journal of Endocrinology 106 55-60. (doi:10.1677/ joe.0.1060055)

Leyva V, Buckrell BC \& Walton JS 1998 Follicular activity and ovulation regulated by exogenous progestagen and PMSG in anestrous ewes. Theriogenology 50 377-393. (doi:10.1016/S0093-691X(98)00147-2)

Li Y, Liang XY, Wei LN, Xiong YL, Yang X, Shi HG \& Yang ZH 2009 Study of RNA interference inhibiting rat ovarian androgen biosynthesis by depressing $17 \alpha$-hydroxylase/17, 20-lyase activity in vivo. Reproductive Biology and Endocrinology 7 73. (doi:10.1186/1477-7827-7-73)

Magoffin DA \& Weitsman SR 1993 Differentiation of ovarian theca-interstitial cells in vitro: regulation of $17 \alpha$-hydroxylase messenger 
ribonucleic acid expression by luteinizing hormone and insulin-like growth factor-I. Endocrinology 132 1945-1951. (doi:10.1210/endo.132. 5.8477646)

McLeod BJ \& Haresign W 1984 Evidence that progesterone may influence subsequent luteal function in the ewe by modulating preovulatory follicle development. Journal of Reproduction and Fertility 71 381-386. (doi:10.1530/jrf.0.0710381)

Medan MS, Watanabe G, Sasaki K, Sharawy S, Groome NP \& Taya K 2003 Ovarian dynamics and their associations with peripheral concentrations of gonadotropins, ovarian steroids, and inhibin during the estrous cycle in goats. Biology of Reproduction 69 57-63. (doi:10.1095/biolreprod. 102.013334)

Monniaux D 1987 Short-term effects of FSH in vitro on granulosa cells of individual sheep follicles. Journal of Reproduction and Fertility $\mathbf{7 9}$ 505-515. (doi:10.1530/jrf.0.0790505)

Monniaux D \& Pisselet C 1992 Control of proliferation and differentiation of ovine granulosa cells by insulin-like growth factor-I and folliclestimulating hormone in vitro. Biology of Reproduction 46 109-119. (doi:10.1095/biolreprod46.1.109)

Monniaux D, Clemente N, Touze JL, Belville C, Rico C, Bontoux M, Picard JY \& Fabre S 2008 Intrafollicular steroids and anti-Müllerian hormone during normal and cystic ovarian follicular development in the cow. Biology of Reproduction 79 387-396. (doi:10.1095/biolreprod. 107.065847)

Oldham CM, Pearce DT \& Gray SJ 1985 Progesterone priming and age of ewe affect the life-span of corpora lutea induced in the seasonally anovulatory Merino ewe by the 'ram effect'. Journal of Reproduction and Fertility 75 29-33. (doi:10.1530/jrf.0.0750029)

Pearce DT \& Oldham CM 1984 The ram effect, its mechanism and application to the management of sheep. In Reproduction in Sheep, pp 27-34. Eds DR Lindsay \& DT Pearce. Cambridge, MA: Cambridge University Press.

Pearce DT, Martin GB \& Oldham CM 1985 Corpora lutea with a short lifespan induced by rams in seasonally anovulatory ewes are prevented by progesterone delaying the preovulatory surge of $\mathrm{LH}$. Journal of Reproduction and Fertility 75 79-84. (doi:10.1530/jrf.0.0750079)

Pearce DT, Oldham CM, Haresign W \& Gray SJ 1987 Effects of duration and timing of progesterone priming on the incidence of corpora lutea with a normal life-span in merino ewes induced to ovulate by the introduction of rams. Animal Reproduction Science 13 81-89. (doi:10.1016/03784320(87)90121-7)

Pellicer-Rubio MT, Touze JL, Baril G \& Malpaux B 2012 The luteal outcome of anoestrus ewes induced to ovulate by the male effect is not related to the population of ovarian antral follicles before male exposure. Animal Reproduction Science 137 23-30. (doi:10.1016/j.anireprosci. 2012.11.010)

Ravindra JP, Rawlings NC, Evans AC \& Adams GP 1994 Ultrasonographic study of ovarian follicular dynamics in ewes during the oestrous cycle. Journal of Reproduction and Fertility 101 501-509. (doi:10.1530/jrf.0. 1010501)
Rosa HJD \& Bryant MJ 2002 The 'ram effect' as a way of modifying the reproductive activity in the ewe. Small Ruminant Research 45 1-16. (doi:10.1016/S0921-4488(02)00107-4)

Sebert ME, Lomet D, Said SB, Monget P, Briant C, Scaramuzzi RJ \& Caraty A 2010 Insights into the mechanism by which kisspeptin stimulates a preovulatory LH surge and ovulation in seasonally acyclic ewes: potential role of estradiol. Domestic Animal Endocrinology 38 289-298. (doi:10.1016/j.domaniend.2010.01.001)

Skinner DC, Evans NP, Delaleu B, Goodman RL, Bouchard P \& Caraty A 1998 The negative feedback actions of progesterone on gonadotropin-releasing hormone secretion are transduced by the classical progesterone receptor. PNAS 95 10978-10983. (doi:10.1073/ pnas.95.18.10978)

Thiery JC \& Malpaux B 2003 Seasonal regulation of reproductive activity in sheep: modulation of access of sex steroids to the brain. Annals of the New York Academy of Sciences 1007 169-175. (doi:10.1196/annals. 1286.017)

Thimonier J, Cognie Y, Lassoued N \& Khaldi G 2000 L'effet mâle chez les ovins: une technique actuelle de maîtrise de la reproduction. INRA Productions Animales 13 223-231.

Ungerfeld R \& Rubianes E 1999 Effectiveness of short-term progestogen primings for the induction of fertile oestrus with eCG in ewes during late seasonal anoestrus. Animal Science 68 349-353.

Vallet JL, Lamming GE \& Batten M 1990 Control of endometrial oxytocin receptor and uterine response to oxytocin by progesterone and oestradiol in the ewe. Journal of Reproduction and Fertility 90 625-634. (doi:10. 1530/jrf.0.0900625)

Van Cleeff J, Karsch FJ \& Padmanabhan V 1998 Characterization of endocrine events during the periestrous period in sheep after estrous synchronization with controlled internal drug release (CIDR) device. Domestic Animal Endocrinology 15 23-34. (doi:10.1016/S07397240(97)00059-3)

Vinoles C, Forsberg M, Banchero G \& Rubianes E 2001 Effect of long-term and short-term progestagen treatment on follicular development and pregnancy rate in cyclic ewes. Theriogenology 55 993-1004. (doi:10. 1016/S0093-691X(01)00460-5)

Walkden-Brown SW, Martin GB \& Restall BJ 1999 Role of male-female interaction in regulating reproduction in sheep and goats. Journal of Reproduction and Fertility. Supplement 54 243-257.

Young JM \& McNeilly AS 2010 Theca: the forgotten cell of the ovarian follicle. Reproduction 140 489-504. (doi:10.1530/REP-10-0094)

Received 23 May 2014

First decision 30 June 2014

Revised manuscript received 22 July 2014

Accepted 25 July 2014 